\title{
Mission of the company, prosocial attitudes and job preferences: a discrete choice experiment
}

Citation for published version (APA):

Non, A., Rohde, I., de Grip, A., \& Dohmen, T. (2019). Mission of the company, prosocial attitudes and job preferences: a discrete choice experiment. Maastricht University, Graduate School of Business and Economics. GSBE Research Memoranda No. 020 https://doi.org/10.26481/umagsb.2019020

Document status and date:

Published: 11/07/2019

DOI:

10.26481/umagsb.2019020

Document Version:

Publisher's PDF, also known as Version of record

\section{Please check the document version of this publication:}

- A submitted manuscript is the version of the article upon submission and before peer-review. There can be important differences between the submitted version and the official published version of record.

People interested in the research are advised to contact the author for the final version of the publication, or visit the DOI to the publisher's website.

- The final author version and the galley proof are versions of the publication after peer review.

- The final published version features the final layout of the paper including the volume, issue and page numbers.

Link to publication

\footnotetext{
General rights rights.

- You may freely distribute the URL identifying the publication in the public portal. please follow below link for the End User Agreement:

www.umlib.nl/taverne-license

Take down policy

If you believe that this document breaches copyright please contact us at:

repository@maastrichtuniversity.nl

providing details and we will investigate your claim.
}

Copyright and moral rights for the publications made accessible in the public portal are retained by the authors and/or other copyright owners and it is a condition of accessing publications that users recognise and abide by the legal requirements associated with these

- Users may download and print one copy of any publication from the public portal for the purpose of private study or research.

- You may not further distribute the material or use it for any profit-making activity or commercial gain

If the publication is distributed under the terms of Article $25 \mathrm{fa}$ of the Dutch Copyright Act, indicated by the "Taverne" license above, 
Arjan Non, Ingrid Rohde, Andries de Grip, Thomas Dohmen

Mission of the company, prosocial attitudes and job preferences: a discrete choice experiment

RM/19/020

\section{GSBE}

Maastricht University School of Business and Economics

Graduate School of Business and Economics

P.O Box 616

NL-6200 MD Maastricht

The Netherlands 


\title{
Mission of the company, prosocial attitudes and job preferences: a discrete choice experiment
}

\author{
Arjan Non ${ }^{1}$, Ingrid Rohde ${ }^{2}$, Andries de Grip ${ }^{3}$, Thomas Dohmen ${ }^{45}$
}

May 2019

\begin{abstract}
We conduct a discrete choice experiment to investigate how the mission of high-tech companies affects job attractiveness and induces self-selection of science and engineering graduates with respect to their prosocial attitudes. We characterize mission by whether or not the company combines its profit motive with a mission on innovation or corporate social responsibility (CSR). Furthermore, we vary job design (e.g. autonomy) and contractible job attributes (e.g. job security). We find that companies with a mission on innovation or CSR are considered more attractive. Women and individuals who are more altruistic and less competitive feel particularly attracted to such companies.
\end{abstract}

Keywords: Mission of the company, sorting, discrete choice experiment, job characteristics, social preferences

JEL codes: J81, J82, M52.

\footnotetext{
${ }^{1}$ Maastricht University, Department of Economics.

${ }^{2}$ University of Bonn, Institute of Applied Microeconomics

${ }^{3}$ Maastricht University, Research Centre for Education and the Labor Market. Corresponding author: a.degrip@maastrichtuniversity.nl

${ }^{4}$ University of Bonn, Maastricht University, and IZA.

${ }^{5}$ We thank Willy Berendsen, Audrey Bink, Jasmijn van den Borne, Jos van Erp, Hans van Loon, Linda Verbeek, and Loulou Zaat for their help in organizing the data collection and their valuable suggestions. We also thank seminar participants at IAB Nürnberg, the University of Padua, and IZA Bonn, as well as conference participants of the $30^{\text {th }}$ conference of the European Association of Labour Economists in Lyon, the $2^{\text {nd }}$ conference of the Asian and Australasian Society of Labour Economics in Seoul, and the 1st KVS new paper sessions in The Hague for valuable comments and suggestions, in particular Josse Delfgaauw. The research was funded by the Dutch Science Organization through grant 407-12-004, project title "Attracting and retaining top talent for the High Tech Systems and materials". Rohde and Dohmen also gratefully acknowledge funding by the Deutsche Forschungsgemeinschaft (DFG, German Research Foundation) through CRC TR 224.
} 


\section{Introduction}

Each organization has a mission: a motive for its existence. Organizations in the private sector naturally have a profit motive, but they often have broader objectives that play a key role in their long-term strategy such as being innovative or being socially responsible. ${ }^{1}$ For example, Tesla prominently advertises its mission "to accelerate the world's transition to sustainable energy", and Philips advertises its mission "to make a healthier, more sustainable world". An organization's mission has strong implications for those who are employed in the organization as it affects what they work on, how their work impacts on society, and the criteria by which their performance is judged. Employees and employers therefore have a shared interest in creating a match between employees' preferences and values and the organization's mission. ${ }^{2}$

Despite the importance of organizations' mission, little is known about how an organization's mission affects the perceived attractiveness of a job, and how it affects the composition of the pool of applicants with regard to their personality traits and attitudes. ${ }^{3}$ For instance, organizations with a mission regarding social responsibility may particularly attract applicants with prosocial attitudes, whereas competitive individuals may feel more at ease in companies that merely focus on making profit. This question is particularly important for organizations that want to hire graduates in science and engineering, since those graduates can choose among a wide range of organizations that value their skills.

This paper investigates the role of company's mission for recruiting prospective employees in the high-tech sector. We conduct a hypothetical discrete choice experiment among master students in science and engineering from the two largest technical universities of the Netherlands $(\mathrm{N}=1498)$. We investigate whether companies with a focus on innovation or corporate social

\footnotetext{
${ }^{1}$ Having objectives besides profit does not imply sacrificing profits, as the objectives can be related to a strategy to ensure long-term profitability. For example, corporate social responsibility may generate goodwill that has immediate returns. Barnett and Salomon (2006) analyze financial performance of 61 socially responsible investment funds and find a $\mathrm{u}$-shaped relation between the number of social screens used and financial performance. Gartenberg et al. (2019) show that companies that are perceived high in purpose by their employees have systematically higher stock market performance, provided management clearly communicates the firm's purpose. Flammer (2015) exploits a regression-discontinuity design to show that corporate social responsibility leads to superior financial performance. Possible channels are higher labor productivity and sales growth.

${ }^{2}$ An often-voiced concern is that workers who do not subscribe to the organization's mission are less satisfied with their job, less motivated, and more likely to leave the organization. According to a recent report by Deloitte on millennials: "In organizational cultures without perceived purpose, only one out of five millennials are satisfied at work" (Smith and Turner, 2017).

${ }^{3}$ Previous literature in economics on job attractiveness has concentrated on the valuation of contractible job attributes and flexible working time arrangements, see e.g. Eriksson and Kristensen (2014), Mas and Pallais (2017), and Wiswall and Zafar (2018).
} 
responsibility (CSR) and sustainability are considered more attractive employers, and whether the mission of the company affects the composition of the workforce with respect to prosocial attitudes, competitiveness and university grade point average. We design a discrete choice experiment in which respondents choose five times among three hypothetical jobs that differ in job design (i.e. autonomy at work, teamwork, and workload), contractible attributes (i.e. wage, performance pay, and job security), and, importantly, mission of the company. We sketch jobs in companies that focus exclusively on maximizing profit, or that in addition to profit focus on innovation or on corporate social responsibility and sustainability. Moreover, we include a nonprofit organization to investigate how applicants value working in a commercial company versus working in a company without profit motive. Respondents trade off these job attributes by ranking the three jobs of each choice set.

Our findings can be summarized as follows. First, mission matters. Keeping all other job aspects constant, potential job applicants prefer to work in commercial organizations that aim to be innovative, as well as in organizations that show corporate social responsibility. At the same time, they do not express a clear preference for working in non-profit organizations over organizations that view making profit as their sole purpose. Commercial organizations with social objectives therefore have a competitive advantage in the labor market. Workers are on average willing to forgo 150 euros in terms of net monthly salary to work in a company that focuses on innovation, and 200 euros to work in a company that focuses on CSR and sustainability. Second, a company's mission affects the composition of the pool of applicants. Non-profit organizations and commercial organizations with social objectives attract more women and applicants who tend to be less competitive and more prosocial than organizations that focus exclusively on profit. We find no evidence that this comes at the cost of attracting less talented individuals, as measured by respondents' grade point average.

The attractiveness of a job also depends on other attributes than the focus of the company. Potential job applicants also highly value autonomy and work in multidisciplinary teams. This is consistent with the idea that workers care about perceived job meaning: according to Cassar and Meier (2018), perceptions of job meaning depend on the organization's mission, autonomy in decision making, and feelings of competence and relatedness. As predicted by standard economic theory, we find that job applicants also care about wages, job security, and workload. Performance pay is valued neither negatively nor positively. We also find some interesting patterns of selfselection. Organizations that offer high job autonomy can expect to attract relatively competitive individuals and more women. A generous salary attracts competitive and selfish individuals. Finally, as we might expect, teamwork is particularly valued by individuals who have high trust in others, and job security is particularly valued by risk averse individuals. 
The first contribution of this paper is that we empirically establish the importance of organizations' mission in the labor market. Previous studies on workers' job preferences have concentrated on contractible job attributes such as fringe benefits and flexible working time arrangements, but have ignored the importance of company mission and job design, see Eriksson and Kristensen (2014), Mas and Pallais (2017), and Wiswall and Zafar (2018). Moreover, previous studies have examined preference heterogeneity by demographic characteristics, but not by economic preferences and personality traits. A few studies complement ours by reporting workers' revealed preference for corporate social responsibility. Burbano (2016) informs randomly chosen workers on two online marketplaces about the social activities of the firm, and find that this information reduced their wage demands by 12 to 44 percent. Bode et al. (2015) analyze data from a large consultancy firm, and find that employees who participate in consultancy projects for charitable organizations are more likely to stay with the firm. Carnahan et al. (2015) examine how law firms' CSR initiatives influence occupation changes of attorneys after the $9 / 11$ terrorist attacks. The idea is that shocking events such as terrorist attacks increase the desire to act prosocially, stimulating individuals to reconsider their career choices. They find that attorneys born in New York City are more likely to quit the profession after the attacks than officemates born outside New York City, who are less likely to be psychologically affected by the attacks. Importantly, this effect is attenuated by pro-bono legal services of the law firms, suggesting that prosocial activities help to reduce turnover of employees who care about their impact on society. Consistent with this interpretation, firms with higher levels of CSR also have lower turnover to different occupations or startup law firms (Carnahan et al., 2017). A difference with our study is that our discrete choice experiment allows us to assess the value of mission relative to several other job attributes. ${ }^{4}$

The second contribution is that we investigate the importance of private sector organizations' mission for attracting prosocial individuals. Previous literature in economics has highlighted the role of individuals' prosociality as a determinant of choice between the public and private sector, see e.g. Banuri and Keefer (2016), Buurman et al. (2012), Dur and Zoutenbier (2014, 2015), Gregg et al. (2011), Hanna and Wang (2017), Jacobsen et al. (2011), and Kolstad and Lindkvist (2013). We extend this research by pointing at the role of mission in the private sector. A number of closely related studies have investigated how job advertisements influence the pool of applicants in public sector jobs. Ashraf et al. (2016) conduct a field experiment in the recruitment

\footnotetext{
${ }^{4}$ A number of studies on job preferences of health care workers in Africa include job attributes such as sector (public/private) and opportunities to help other people (Lagarde and Blaauw, 2016, Doiron et al., 2014, and Kolstad, 2011). However, these studies are conducted in a markedly different context than ours, and are silent on the selection effects of the mission of the organization.
} 
of health workers in Zambia. They experimentally vary whether the job advertisement emphasizes career prospects or contribution to society, and find that emphasizing career prospects attracts individuals who provide more services and produce better health outcomes. Likewise, Dal-Bó et al. (2013) find that a higher advertised salary for public sector workers in Mexico attracts workers who are more productive. ${ }^{5}$

We also contribute to the literature in management and personnel psychology on applicant attraction. An important concept in this literature is Person-Organization fit (P-O fit), which is often operationalized as the match between individuals' values and their perception of the organization's values (Evertz and Süss, 2017; Kristof, 1996). According to meta-analyzes by Chapman et al. (2005) and Uggerslev et al. (2012), perceptions of P-O fit are key drivers of applicant attraction. Only few studies, however, have investigated fit between individuals' prosocial values and organizations' mission. ${ }^{6}$

A final contribution is that we focus on students in science and engineering who are about to enter the labor market. These students potentially have a high impact on technological innovation and economic growth in their later careers (Murphy et al., 1991). However, their societal impact will also depend on the mission of the organizations they end up working for. This makes studying their job preferences particularly relevant. Moreover, given the social relevance of high-tech products, companies in high-tech sectors have ample opportunities to communicate their relevance for society to potential job applicants.

The paper proceeds as follows. Section 2 describes the discrete choice experiment and its theoretical background, the measurement of personality characteristics, social and economic preferences as well as the main characteristics of the sample. In sections 3 and 4, we discuss the estimation method and results, respectively. Section 5 concludes.

\footnotetext{
${ }^{5}$ There is also a substantial literature on the effect of mission on worker motivation and the complex interplay with financial incentives, e.g. for example Ariely et al. (2009), Ashraf et al. (2014), Imas (2014), Carpenter and Gong (2016), Fehrler and Kosfeld (2014), Gerhards (2015), Tonin and Vlassopoulos (2010, 2015), and Cassar (2019). Laboratory experiments by Fehrler and Kosfeld (2014) and Tonin and Vlassopoulos (2015) also include treatments that allow individuals to self-select into mission-oriented organizations, represented by working for the benefit of a charity of their own choice. However, they do not relate these preferences to individuals' prosocial attitudes. Another difference is that, other than in many real-life situations, the social dimension is not intrinsically bundled with the production of the good: effort is not helping others except for the charity contribution.

${ }^{6}$ Gully et al. (2013 experimentally vary job advertisements by extending the desired applicant profile with social and environmental consciousness. They find that the modified job advertisement makes the organization more attractive for job seekers who desire to make a significant societal impact through work. Evans and Davis (2011) and Zhang and Gowan (2012 study the role of CSR in applicant attraction, and its relation to other-regarding values and ethical predispositions, respectively. They specifically define CSR as legal compliance, fair treatment of stakeholders, and transparency, which is more narrow than what we have in mind.
} 


\section{Methods}

\subsection{Experimental design}

\section{A. 2.1.1. Discrete choice experiment}

Discrete choice experiments have two important advantages over naturally occurring revealed preference data. First, discrete choice experiments allow the researcher to vary job attributes exogenously, which is rarely observed in naturally occurring data. Second, in experimental data all available choice options are observed, including the options that are not chosen. Studies on actual behavior are typically not able to identify all options available.

An obvious concern of discrete choice experiments is their external validity. Hainmüller et al. (2015) provide a validation of this methodology by comparing preferences for migrant characteristics derived from discrete choice experiments with actual voting behavior in referenda on naturalization. They show that experimentally elicited stated preferences are close to revealed preferences when the experimental design forces participants to make trade-offs, as is the case in our design. More generally, they conclude that respondent engagement with the choices to be made is a key factor for the reliability of the results.

We design our discrete choice experiment specifically for MSc students. Focusing on this group has a number of advantages. First, MSc students are about to enter the labor market. They therefore have strong incentives to think carefully about their job preferences, resulting in high engagement with the survey topic. Second, students are a homogeneous group in terms of age and stage of their career, which facilitates the interpretation of the results.

The core of our discrete choice experiment consists of the rankings respondents make among three hypothetical jobs in five different choice sets. Figure 1 shows a screenshot to illustrate how we present the task to participants. The screen shows a choice set with three jobs, which respondents are asked to rank according to their preferences. Each of the five choice sets is presented on a separate screen. This design balances respondent load and the amount of information we collect. We opt for a rank-order design instead of ratings, since we want to force individuals to make choices. ${ }^{7}$

\footnotetext{
${ }^{7}$ An alternative would be to impose that respondents discriminate jobs in their ratings, but this increases complexity without providing much additional information.
} 
Jobs in each choice set differ in eight job attributes that are exogenously varied. As all jobs are randomly generated, each respondent evaluates different choice sets. The values of each job attribute are randomly drawn from the set of possible values. The randomization is subject to two constraints. First, we rule out that a job attribute takes on three times the same value in a choice set. This ensures that there is variation in each attribute within each choice set, which increases the information implicit in respondents' choices. $^{8}$ Second, we rule out two implausible combinations of job attributes. If work is conducted on one's own, pay-for-performance is never based on team performance, but always on individual performance. Vice versa, if work is conducted in teams, performance pay is not based on individual performance. Although these combinations are theoretically possible (profit-sharing, pay based on peer assessment), their inclusion might well confuse respondents.

One might be concerned that respondents find it daunting to compare jobs that differ in eight dimensions. This complexity may increase noise in the answers, but it also adds realism as in practice jobs also differ along several important dimensions.

\section{B. 2.1.2. Choice of attributes and attribute values}

Jobs differ in the following attributes, which can be grouped into three categories:

1. Mission of the company: focus of the company.

2. Job design: autonomy, teamwork and workload.

3. Contractible characteristics: salary, performance pay, and job security.

Furthermore, we include occupation (Research and Development, Management, Sales) in the experiment and in our analyses, but we do not report the results for ease of presentation. ${ }^{9}$

We based our selection of job attributes on practical relevance. As a starting point, we screened job advertisements on one of the largest job fairs for MSc students in engineering in the Netherlands, which takes place annually at the Eindhoven University of Technology. We used this information to discuss the importance of several job attributes with recruiters in the high-tech sector as well as employer representatives of the sector.

\footnotetext{
${ }^{8}$ Note that this procedure does not preclude the possibility that subjects incidentally see the same job twice in a choice set, but this happened in only two out of 7,490 choice sets. More generally, 36 subjects evaluate the same job in different choice sets.

${ }^{9}$ Results on occupation are relevant for employers in high-tech sectors, but they are also context-specific and therefore less interesting from a scientific perspective. Results are available upon request.
} 
Table 1 provides an overview of job attributes and the corresponding values. We designed attribute values in such a way that they are realistic and sufficiently specific to allow for meaningful comparisons. We are particularly interested in the focus of the company. We distinguish between two dimensions: profit motive and contribution to society. On the one extreme, we pitch an organization that is strongly driven by profit. The other extreme is a nonprofit organization, which encompasses a wide variety of organizations (e.g. government, charity, university, research institute). Commercial organizations with a pro-social mission fall in between: they combine a profit motive with a mission on innovation and/or CSR and sustainability.

Furthermore, we quantified job attributes as much as possible. We used our discussions with recruiters and employers in the high-tech sector to determine what variation in attribute values would be realistic. For example, starting salaries of MSc graduates in the sector typically hoover between 1800 and 2200 euro net per month. Likewise, performance pay components, when present, are usually responsible for roughly $10 \%$ higher or lower wages in this sector. We also took care to make abstract attributes such as autonomy and teamwork as specific as possible. In case we had to trade off realism and specificity of attribute values we gave priority to the latter. This resulted in stylized descriptions of attribute values that are more extreme than what we most often observe in practice (e.g. high-skilled work always entails some team component). However, we think that making abstract attributes more explicit helps respondents to understand their importance and to express their preferences.

\subsection{Measurement of personality characteristics}

We collect information on a variety of background characteristics such as age, gender, nationality (defined as country of birth) and study specialization (i.e. master program). Moreover, in our survey we included the following measures of personality characteristics and economic preferences:

Altruism: We use two questions proposed by Falk et al. (2016) to measure altruism:

1. "How would you assess your willingness to share with others without expecting anything in return, for example your willingness to give to charity?" (Extent of agreement expressed on a continuous scale from 0 to 10.)

2. "Imagine the following situation: Today you unexpectedly received 1000 Euro. How much of this amount would you donate to charity? (Any value between 0 and 1000 is allowed)" 
Falk et al. (2016) identify these questions as the best available survey measures of altruism, since they are the best predictors of altruistic behavior in an incentivized experiment (transfers in a dictator game with a charitable organization as recipient). We take the first principal component of these two questions to construct our measure of altruism.

Competitiveness: We measure competitiveness with a selection of items from the Revised Competitiveness Index (Houston et al. 2002). We use the following three items:

1. I try to avoid competing with others (reversed)

2. I don't like competing against other people (reversed)

3. I like competition

The full scale consists of fourteen items, but we select three items to reduce survey length. We base the selection of these items on an analysis of the full scale, exploiting data collected among university students where we elicited the full scale as part of an unrelated laboratory experiment $(\mathrm{N}=240)^{10}$. We select the three items that jointly show the highest correlation with the full scale ( 0.94 for the items mentioned above). Respondents express their extent of agreement with each of those statements on a five-point scale.

Trust: We measure trust by asking subjects to what extent they agree with the following statements (five-point scale):

1. On the whole, one can trust people

2. Nowadays, one can't rely on anyone (reversed)

3. If dealing with strangers, it is better to be careful before one can trust them (reversed)

Those items are taken from the German Socio-Economic Panel (SOEP) and are validated by Fehr et al. (2002).

Grade: We measure academic achievement with the grade obtained in the master program so far. Grades in the Netherlands are always expressed on a scale 1 (lowest) to 10 (highest), where 5.5 is the minimum passing grade. Only $2.4 \%$ of the sample reports an average grade below 5.5 , and roughly $50 \%$ of all grades are between 7 and 8 (bounds included).

Self-Efficacy: We measure self-efficacy with a selection of items from the New General SelfEfficacy Scale (Chen et al., 2001). We use the following three items:

\footnotetext{
${ }^{10}$ Results are available upon request. The sample of this lab experiment mainly consist of business and economics student.
} 
1. I will be able to achieve most of the goals that I have set for myself.

2. I will be able to successfully overcome many challenges.

3. Compared to other people, I can do most tasks very well.

While the original scale consists of 14 items, we selected three items based on the same procedure we used to select items from the competitiveness index. We exploit questionnaire data from an unrelated laboratory experiment among university students $(\mathrm{N}=240)$ to select the three items that jointly show the highest correlation with the full scale. The three items we selected have a 0.95 correlation with the original 14-item scale.

Risk tolerance: We measure individuals' attitude towards risk by a widely used subjective risk question (see Falk et al., 2016 and Dohmen et al., 2011, for validation of this measure). Respondents indicate on a continuous scale from 0-10 to what extent the following statement applies to them: "How do you see yourself: are you a person who is generally willing to take risks, or do you try to avoid taking risks?"

\subsection{Data}

Our sample consists of MSc students in science and engineering from the two largest technical universities of the Netherlands: Delft and Eindhoven. In the Netherlands, MSc programs in science and engineering take two years. We approached both first and second-year MSc students. The surveys were conducted in March 2015 (Eindhoven) and July 2016 (Delft). We collected 595 and 903 valid responses (15\% and 10\% of the approached population in Eindhoven and Delft, respectively). Table 2 provides descriptive statistics of the main variables. Overall, student populations of the two universities are comparable in terms of observable characteristics. At both universities, non-Dutch students predominantly come from China and India (13\% in Delft and 14\% in Eindhoven) and other European countries (10\% in Delft and 9\% in Eindhoven).

We also collected descriptive statistics on the population of registered MSc students of both universities. Compared to the overall population, it seems that women are overrepresented in our sample (Delft: $36 \%$ in the sample vs $27 \%$ in the population; Eindhoven: $27 \%$ in the sample vs $20 \%$ in the population). Students with Dutch nationality are somewhat underrepresented (Delft: $61 \%$ in the sample vs $68 \%$ in the population; Eindhoven: $64 \%$ in the sample vs $82 \%$ in the population). ${ }^{11}$ 
Table 3 reports correlations between the various personal characteristics, personality traits and preferences. Most correlations have the expected sign. For example, competitive individuals score higher on self-efficacy, are less altruistic, and more willing to take risks. Women tend to be less competitive than men. As expected, self-efficacy and grades are positively correlated $(\mathrm{r}=0.15)$. Dutch students appear more trusting and less altruistic than students from other countries. Note that this may not only reflect cultural differences, but also selection effects, as well as differences in the interpretation of questions.

\section{Econometric Framework}

To exploit all available information in the choices respondents make, we estimate mixed rankordered logit models. This model is developed to analyze choices individuals make in a number of different choice situations. ${ }^{12}$ The analysis of such data requires methods that deal with the discrete and ordinal nature of choice data, as well as the correlation that arises naturally across choice situations. When an individual has a particularly strong preference for one attribute, this preference influences his or her choices in all choice situations. Individuals' choices can therefore not be treated as independent observations. Mixed rank-ordered logit models address this in a natural way by allowing the preference parameters to differ over individuals. ${ }^{13}$

The model is based on the assumption that individuals choose the alternative that maximizes their utility. The utility function consists of a systematic and stochastic part. Specifically, utility of alternative $j$ in choice situation $t$ for individual $i$ is described by:

$$
U_{i j t}=\beta_{i}^{\prime} x_{j t}+\gamma^{\prime} x_{j t} * z_{i}+\varepsilon_{i j t},
$$

where $\beta_{i}$ and $\gamma$ are coefficient vectors, $x_{j t}$ is a vector with job attributes, $z_{i}$ is a vector with individual characteristics, and $\varepsilon_{i j t}$ is an error term. The error term $\varepsilon_{i j t}$ is independent and identically (iid) extreme-value distributed. The defining characteristic of the mixed rank-ordered logit model is that the coefficient vector $\beta_{i}$ differs over individuals. The coefficients are assumed

as the population we approached. For instance, our sample includes exchange students, which may explain why we have relatively more non-Dutch students. In the absence of more detailed information, it is not possible to make precise comparisons.

${ }^{12}$ Useful introductions to mixed logit models are Revelt and Train (1998), Layton (2000), Lancsar et al. (2017) and Hensher and Greene (2003).

${ }^{13}$ The less complicated rank-ordered logit models can deal with the discrete and ordinal nature of rankordered choice data, but ignore the correlation between choice observations. 
to be normally distributed with mean $\beta$ and variance $\theta$. This is the main difference with the standard rank-ordered logit model, which assumes that $\beta_{i}$ is the same for all individuals, i.e. $\beta_{i}=\beta$. Since individuals' preferences for job attributes are likely to be correlated, we allow the individual-specific parameters to be correlated. ${ }^{14} \mathrm{We}$ are also interested in the parameter vector $\gamma$, which captures the interaction between job characteristics and individual characteristics such as gender, grade, and social preferences. The interaction terms allow the valuation of job characteristics to differ systematically between individuals, and are therefore not individualspecific.

Individuals choose the alternative $j$ from choice set $t$ that gives them highest utility. The probability that individual $i$ prefers alternative $j$ over all alternatives $k$ in choice set $t$ is therefore described by:

$$
P_{i j t}=\operatorname{Pr}\left(U_{i j t}-U_{i k t}>0\right), \quad \forall k \neq j
$$

As utility depends on the iid extreme-value distributed error term $\varepsilon_{i j t}$, the probability that individual $i$ chooses alternative $j$ is described by:

$$
P_{i j t}=\frac{e^{\beta_{i}^{\prime} x_{j t}+\gamma^{\prime} x_{j t} * z_{i}}}{\sum_{j} e^{\beta_{i}^{\prime} x_{j t}+\gamma^{\prime} x_{j t} * z_{i}}}
$$

The sequence of choices made by individual $i$ occurs with probability

$$
S_{i}=\prod_{t=1}^{T} \frac{e^{\beta_{i}^{\prime} x_{j t}+\gamma^{\prime} x_{j t} * Z_{i}}}{\sum_{j} e^{\beta_{i}^{\prime} x_{j t}+\gamma^{\prime} x_{j t} * z_{i}}}
$$

We estimate the parameters $\beta_{i}$ and $\theta$ that maximize this probability using simulated maximum likelihood.

We do not allow all coefficients to differ between individuals. We assume that individuals equally value a higher wage, so that we can use the wage as a common metric to compute the implied monetary value of job attributes. Also, we control for order effects to obtain more precise

\footnotetext{
${ }^{14}$ For instance, consider an individual who greatly cares about making a difference in the life of others. It is likely that this individual cares more than average about both focus of the company and job autonomy, so that he or she can also decide on the exact way to help others. See Hess and Train (2017) for further examples. Failure to take this correlation into account could lead to over- or underestimation of the marginal rates of substitution.
} 
estimates: we include dummy variables that indicate whether a job is presented on the left of the screen, in the center, or on the right. ${ }^{15}$

The rank ordered logit is also referred to as exploded logit, because it exploits information on the preference relations that are revealed by the ranking. Assuming that the ranking process is sequential, respondents first choose the most attractive alternative from the choice set, and then choose the most attractive option out of the remaining alternatives. ${ }^{16}$ The data is 'exploded' to represent this choice process, which means in our case that the dataset is transformed to record the preferred option among the three alternatives as well as between the two remaining alternatives. This implies that we have five observations per choice set. As each individual is confronted with five choice sets, the total number of observations in the estimations is equal to 25 times the number of respondents. The mixed rank-ordered logit model is estimated as mixed logit on the 'exploded' data. All reported estimations are based on 200 Halton draws to approximate the log-likelihood function, see Lancsar et al. (2017) for a discussion of the tradeoffs involved.

\section{Results}

\subsection{Average preferences for job attributes}

The analysis proceeds in two steps. First, we estimate a mixed rank-ordered logit model to establish the average value of each job attribute. In terms of the econometric model explained above, we estimate the parameters $\beta_{i}$ assuming $\gamma=0$. Next, in Section 4.2, we interact job attributes with individual characteristics to examine how job preferences differ by individual characteristics.

Table 4 presents the estimation results. The first column reports the mean estimated coefficients, the second column the estimated standard deviation of the individual coefficients. Note that the dependent variable (rank 1-3) is inverted, so that positive coefficients indicate higher

\footnotetext{
${ }^{15}$ Dummies indicate whether a job was presented as job A, B, or C (see Figure 1). We do not allow these order effects to differ over individuals. Jobs presented in the middle column (job B) are chosen more frequently, while jobs presented on the right of the screen are least preferred. Those order effects are small in magnitude. Correcting for order effects increases the precision of the estimates.

${ }^{16}$ A limitation is that, under the assumption of transitivity, we ignore the information implicit in evaluations of the same job in different choice sets. However, this situation occurs only 36 times in our data.
} 
levels of attractiveness. ${ }^{17}$ Coefficients can be interpreted as log odds, or after exponentiating, odds ratios.

Concerning the mission of the company, we find that respondents have a clear preference for working in a commercial organization with a focus on innovation or CSR \& sustainability. Respondents find working for a non-profit organization less desirable, although they still prefer non-profit organizations over organizations that focus exclusively on making profit. These differences are statistically significant at the one percent level. The odds that a job in a company with a focus on innovation is chosen are 50 percent higher than when the company would focus on profit.

All other job attributes are also significantly related to job rank, with the noteworthy exception of pay-for-performance. ${ }^{18}$ Respondents positively value autonomy and teamwork, in particular work in multidisciplinary teams. Those findings are consistent with the idea that individuals care about job meaning in the sense of Cassar and Meier (2018), who define job meaning as a function of mission, autonomy, feelings of competence and relatedness. Moreover, respondents care about salary, workload, and a (reasonable perspective on a) permanent contract. Moving from a low salary to a high salary and from no autonomy to full autonomy has the largest impact on the odds that a job is preferred. It is important to take into account that the effect sizes are evaluated relative to the reference category: $€ 400$ additional monthly salary is a substantial difference. Likewise, university graduates are unlikely to be offered a job with no autonomy at all. The estimated variation in individual coefficients gives an indication of preference heterogeneity. Opinions seem generally divided, as the estimated variation is substantial for most attributes. ${ }^{19}$

The value of job attributes can be expressed in monetary terms by comparing the estimated coefficients with the estimated effect of a $€ 200$ wage increase. The third column in Table 4 provides an overview of the implied monetary value of each job attribute, while Figure 2 provides a graphical illustration. ${ }^{20}$ The estimated value of a mission on innovation or CSR is

\footnotetext{
${ }^{17}$ This rank-order reversion is implicit in the 'exploded' data structure.

${ }^{18}$ Note that the performance-based wage component in our experiment is $10 \%$ of the wage, which corresponds with the experimental variation in salary levels. It is therefore hard to argue that the performance-based wage variation is too small. Perhaps individuals are generally confident that they will meet performance targets, or they do not mind wage fluctuations because they expect to be capable of income smoothing.

${ }^{19}$ In fact, the implied coefficients are negative for some individuals and positive for others. We should not overinterpret this finding, however, since negative coefficients might be an artefact of the assumed normal distribution of the parameters.

${ }^{20}$ We divide the estimated coefficient of each job attribute by the average value of a $€ 200$ wage increase. Specifically, we divide all coefficients by $1 / 2\left(\beta_{€ 2000}+1 / 2 \beta_{€ 2200}\right)$, where $\beta_{€ 2200}$ is the increase in attractiveness of a job that pays $€ 2200$ relative to a job that pays $€ 1800$.
} 
roughly worth the equivalent of a $€ 150-€ 200$ monthly net salary raise, respectively. Work in multidisciplinary teams (rather than individual work) and full job autonomy and are even worth the equivalent of $€ 300$ and $€ 400$ monthly net salary raise, respectively. Individuals also demand more than $€ 300$ compensation for regularly working overtime.

We should, however, be careful interpreting these numbers. First, it should be noted that there is substantial preference heterogeneity, implying that observed wage differentials will be much smaller due to self-selection. For example, organizations will not compensate workers with $€ 300$ higher salary for working overtime frequently as long as there are sufficient workers who do not mind working overtime so much and are therefore satisfied with a lower compensation. Second, in practice not all job characteristics are easily observable for potential applicants, and observable characteristics may signal the presence of unobservable characteristics. The valuation of a $€ 200$ higher salary is therefore not clear when it is also perceived to signal high workload or high job autonomy. Third, applicants may view organizations' prosocial mission statements with skepticism when they are not backed up by their products and policies. Similar credibility issues may arise in communications regarding work load and job autonomy. With these caveats in mind, we can conclude that, ceteris paribus, workers are on average willing to accept a $€ 200$ lower wage when the organization has a prosocial mission.

We also conducted a short follow-up survey among a subset of respondents three years after the initial survey $(\mathrm{N}=108)$. This gives us an impression whether the job characteristics included in our hypothetical choice experiment relate to job satisfaction. We describe the results in the appendix. Given the small number of observations we should be careful not to overinterpret the findings, but the overall pattern is consistent with the findings from the hypothetical choice experiment. Workers who report that their organization emphasizes innovation report higher job satisfaction. Likewise, we find that job autonomy, job security and monodisciplinary teamwork are positively valued.

\subsection{Heterogeneity in preferences by personality traits and economic preferences}

The next step in the analysis is to examine heterogeneity in job preferences by personality. We therefore extend the mixed rank-ordered logit model with interactions between the job attributes and personality characteristics. As before, all main effects except for wage are allowed to vary over individuals. We also include interaction terms to control for university (Eindhoven 
or Delft) and nationality. ${ }^{21}$ Table 5 reports the estimation results. Columns 1 and 2 show the mean estimated coefficients and their standard deviations for the reference category, which is a male Dutch student from the Delft University of Technology.

\section{A. Mission of the company}

We find that women have a stronger preference for working in a non-profit or a for-profit with a prosocial mission than men. These effects are statistically significant at the one percent level after controlling for personality characteristics. Gender differences in mission preferences therefore do not seem to be driven by gender differences in competitiveness or altruism. ${ }^{22}$ The effect is sizeable. For instance, men are 1.74 times more likely to prefer a for-profit with a focus on innovation over a profit oriented company, whereas women are 2.34 times more likely to do so. Organizations with a prosocial mission are also more likely to attract individuals with prosocial attitudes: individuals who are less competitive and those who are more altruistic. ${ }^{23}$ One standard deviation increase in competitiveness reduces the odds that a for-profit with a focus on innovation is preferred over a profit oriented company from 1.74 to 1.54 . The effect of competitiveness on preferences for mission on CSR is in the same order of magnitude.

\section{B. Job design}

Various attributes of job design also induce self-selection of job applicants. Teamwork is particularly valued by individuals who have high trust in others. This is consistent with the economic intuition that individuals who have high trust in others are less concerned about freerider behavior of team members.

Selection effects of autonomy are less clear. We do not find a relation with self-efficacy, and only a weak relation with academic achievement. Specifically, we find a significant interaction between individuals' grade point average and the intermediate level of autonomy, but not the highest level of autonomy. The desire for job autonomy therefore seems independent of perceived

\footnotetext{
${ }^{21}$ For ease of presentation we do not report the coefficients of the other variables included in the model, i.e. order effects and job attributes interacted with university and nationality.

${ }^{22}$ We cannot rule out that gender differences in competitiveness or altruism drive gender differences in mission preferences. Both attitudes are hard to measure precisely, while gender is measured without error. However, gender differences in competitiveness and altruism are small in this sample (see correlations in Table 3).

${ }^{23}$ As mentioned, our measure of altruism consists of two questions: willingness to share with others and willingness to contribute to charity. Results are comparable when we use either of the two measures.
} 
ability. ${ }^{24}$ Job autonomy seems to be particularly valued by women. This might be related to the finding that women care more about the 'meaning' of their job to society at large, so it is natural that they also want to contribute significantly to reaching that objective.

High workload induces a selection effect that is hard to interpret. Risk tolerant individuals seem to have less problems with working overtime, and this effect is statistically significant at the $1 \%$ level. A possible interpretation of this finding is that risk-tolerant individuals are willing to risk their health and social relations for their career. However, in the absence of empirical evidence on this specific mechanism we should be careful not to overinterpret this finding.

\section{Contractible aspects}

A straightforward way to increase the attractiveness of a job is to offer a competitive salary. Our results confirm this standard economic prediction. However, higher salaries may also change the composition of the pool of applicants. The results reported in Table 5 suggest that competitive and selfish individuals particularly value high salaries, which is consistent with previous findings of Reuben et al. (2015, 2017) and Kamas and Preston (2018). These effects are statistically significant at the one percent level. We also find that paying high salaries is not an efficient way to attract high-achieving students. If anything, high-achieving students have a lower valuation of salary than low-performing students. Finally, risk tolerant individuals seem to have a higher valuation of salary, which is hard to interpret.

As discussed above and shown in Table 4, pay for performance does not seem to affect average job attractiveness. It is therefore interesting to examine whether individuals with high perceived ability or risk tolerance have a higher valuation of pay for performance than individuals with low perceived ability or risk tolerance. We do not find evidence for this: the valuation of pay for performance does not differ by grades, self-efficacy, or risk attitude. The estimation results suggest a gender difference: women appear to shy away from individual pay for performance, but not from team-based pay for performance.

Finally, offering job security affects the composition of the pool of applicants. In line with economic theory, risk tolerant individuals care less about obtaining a permanent contract.

\footnotetext{
${ }^{24}$ This is not because grades and self-efficacy are highly correlated: we obtain the same results when including these characteristics separately.
} 


\section{Concluding Remarks}

This paper provides evidence that high tech companies with a mission focusing on innovation or CSR have a competitive advantage on the labor market. Companies that provide employees with the opportunity to work on innovative projects or on making responsible and sustainable products can save on wages. Keeping all other job attributes constant, workers are on average willing to give up between $€ 150$ and $€ 200$ net per month.

We also observe systematic heterogeneity in the valuation of attributes that may induce important selection effects in labor markets: companies that focus on innovation or CSR and sustainability are considered particularly more attractive by women and individuals who are relatively altruistic and less competitive. This insight is important for organizations for a number of reasons. First, since gender diversity is a common concern in the male-dominated field of engineering, it is important to know that a prosocial focus of the company can contribute to gender diversity in the workplace. Second, companies may benefit from attracting altruistic and lesscompetitive workers, since workers with those attitudes arguably cooperate more effectively, and in particular when they feel motivated by the mission of the company.

Besides mission of the company, we identify a number of other job attributes that individuals care about when choosing between jobs. Those attributes include traditional economic aspects such as salary, workload, and job security as well as important elements of job design such as autonomy and teamwork. We also find a number of other interesting sorting patterns. Job autonomy is particularly valued by women. Teamwork is highly valued by individuals who have high trust in others. A high salary is considered especially attractive by competitive and selfish individuals. Finally, the job security of a permanent contract attracts risk averse individuals.

Organizations can use these insights strategically, and craft their organization and jobs in such a way that they attract the types that possess the traits and preferences that are most productive in a particular environment. Clearly, not all job attributes can easily be changed (e.g. occupation, absence of profit motive), but many aspects can be changed or emphasized more in job advertisements and recruitment procedures more broadly. For example, an organization with a strong focus on CSR and sustainability that is looking for a workforce with a competitive attitude can pay high salaries to attract those types. Also, organizations can often improve on the marketing of CSR initiatives to their employees (Bhattacharya et al., 2008).

We consider our research as a first step to learn about the valuation and sorting effects of immaterial job attributes, and mission in particular. Future research could investigate in more detail why workers value a prosocial focus of the company. For instance, they may care about the contribution of their work to society, but they may also believe that organizations with a prosocial 
mission have better chances to survive in the long run. Alternatively, they may perceive an organization's prosocial mission as a signal that the organization also cares for its employees, or, in line with the findings of our study, that the work atmosphere it better because the workforce is more prosocial. Furthermore, our discrete choice experiment is specifically designed for engineers at the start of their career, and therefore particularly relevant for firms in the high-tech sector. Future research could explore the generality of the findings for other sectors, or among workers who have more experience or obtained less education. Another interesting question is to what extent organizations are aware of the sorting mechanisms described in this paper. Do they attract the people they would like to attract? It would also be interesting to learn how attracting different worker types translates into productivity changes. Those questions are left for further research. 


\section{References}

Ariely D, Bracha A, Meier S (2009) Doing Good or Doing Well? Image Motivation and Monetary Incentives in Behaving Prosocially. American Economic Review 99: 544-555.

Ashraf N, Bandiera O, Jack K (2014) No Margin No Mission? A Field Experiment on Incentives for Public Services Delivery. Journal of Public Economics 120: 1-17.

Banuri, S, and Keefer, P (2016) Pro-social motivation, effort and the call to public service. European Economic Review, 83: 139-164.

Barnett ML, Salomon RM (2006) Beyond dichotomy: The curvilinear relationship between social responsibility and financial performance. Strategic management journal, 27(11): 1101-1122.

Besley T, Ghatak M (2017) Profit with Purpose? A Theory of Social Enterprise. American Economic Journal: Economic Policy 9: 19-58.

Bhattacharya CB, Sen S, Korschun D (2008). Using corporate social responsibility to win the war for talent. MIT Sloan management review 49(2): 37-44.

Bode C, Singh J, Rogan M (2015) Corporate social initiatives and employee retention. Organization Science 26(6): 1702-1720.

Burbano VC (2016) Social responsibility messages and worker wage requirements: Field experimental evidence from online labor marketplaces. Organization Science 27(4): 1010-1028.

Buurman M, Delfgaauw J, Dur R, Van den Bossche S (2012) Public Sector Employees: Risk Averse and Altruistic? Journal of Economic Behavior and Organization 83: 279-291.

Cadsby CB, Song F, Tapon F (2007) Sorting and Incentive Effects of Pay-for-Performance: An Experimental Investigation. The Academy of Management Journal 50: 387-405.

Carnahan S, Kryscynski D, Olson D (2015) How corporate social responsibility reduces employee turnover. In: Academy of Management Proceedings (Vol. 2015, No. 1, p. 14792). Briarcliff Manor, NY 10510: Academy of Management.

Carnahan S, Kryscynski D, Olson D (2017). When does corporate social responsibility reduce employee turnover? Evidence from attorneys before and after 9/11. Academy of Management Journal, 60(5), 1932-1962.

Carpenter J, Gong E (2016) Motivating Agents: How much does the Mission matter? Journal of Labor Economics 34: 211-236.

Cassar, L. (2019) Job Mission as a Substitute for Monetary Incentives: Benefits and Limits. Management Science, 65(2): 896-912. 
Cassar L, Meier S (2018) Nonmonetary Incentives and the Implications of Work as a Source of Meaning. Journal of Economic Perspectives 32(3): 215-38.

Chapman DS, Uggerslev KL, Carroll SA, Piasentin KA, Jones DA (2005) Applicant Attraction to Organizations and Job Choice: A meta-analytic Review of the Correlates of Recruiting Outcomes. Journal of Applied Psychology 90: 928-944.

Chen G, Gully SM, Eden, D. (2001) Validation of a New General Self-Efficacy Scale. Organizational Research Methods 4: 62-83.

Dal Bó E, Finan F, Rossi MA (2013) Strengthening State Capabilities: The Role of Financial Incentives in the Call to Public Service. The Quarterly Journal of Economics 128: 1169-1218.

Dohmen T, Falk A (2011) Performance Pay and Multidimensional Sorting: Productivity Preferences and Gender. American Economic Review 101: 556-590.

Dohmen T, Falk A, Huffman D, Sunde U, Schupp J, Wagner GG (2011) Individual Risk Attitudes: Measurement Determinants and Behavioral Consequences. Journal of the European Economic Association 9: 522-550.

Doiron D, Hall J, Kenny P, Street DJ (2014) Job preferences of students and new graduates in nursing. Applied Economics 46: 924-939.

Dur R, Zoutenbier R (2014) Working for a Good Cause. Public Administration Review 74: 144155 .

Dur R, Zoutenbier R (2015) Intrinsic Motivations of Public Sector Employees: Evidence for Germany. German Economic Review 16: 343-366.

Eriksson T, Kristensen N (2014) Wages or Fringes? Some Evidence on Trade-Offs and Sorting. Journal of Labor Economics 32: 899-928.

Evans R, Davis WD (2011) An Examination of Perceived Corporate Citizenship Job Applicant Attraction and CSR Work Role Definition. Business \& Society 50: 456-480.

Evertz L, Süss S. (2017) The Importance of Individual Differences for Applicant Attraction: a Literature Review and Avenues for Future Research. Management Review Quarterly 67: 141174.

Falk A, Becker A, Dohmen T, Huffman D, Sunde U (2016) The Preference Survey Module: A Validated Instrument for Measuring Risk Time and Social Preferences. IZA Discussion Paper No 9674. 
Fehr E, Fischbacher U, Von Rosenbladt B, Schupp J, Wagner GG (2002) A Nation-Wide Laboratory. Schmollers Jahrbuch 122: 519-542.

Fehrler S, Kosfeld M (2014) Pro-Social Missions and Worker Motivation: An Experimental Study. Journal of Economic Behavior and Organization 100: 99-110.

Flammer C (2015) Does Corporate Social Responsibility lead to Superior Financial Performance? A Regression Discontinuity Approach. Management Science 61: 2549-2568.

Gartenberg C, Prat A, Serafeim G (2019) Corporate purpose and financial performance. Organization Science 30(1): 1-18.

Gerhards L (2015) The incentive effects of missions-Evidence from experiments with NGO employees and students. European Economic Review 79: 252-262.

Gregg P, Grout PA, Ratcliffe A, Smith S, Windmeijer F (2011) How Important is Pro-Social Behaviour in the Delivery of Public Services? Journal of Public Economics 95: 758-766.

Gully SM, Phillips JM, Castellano WG, Han K, Kim A. (2013) A Mediated Moderation Model of Recruiting Socially and Environmentally Responsible Job Applicants. Personnel Psychology 66: 935-973.

Hainmüller J, Hangartner D, and Yamamoto T (2015) Validating Vignette and Conjoint Survey Experiments against Real-World Behavior. Proceedings of the National Academy of Science 112: $2395-2400$.

Hanna, R, and Wang SY (2017). Dishonesty and selection into public service: Evidence from India. American Economic Journal: Economic Policy, 9(3), 262-90.

Hensher DA, Greene WH (2003) The mixed logit model: the state of practice. Transportation 30(2): 133-176.

Hess S, Train KE (2017) Correlation and scale in mixed logit models. Journal of Choice Modelling 23: 1-8.

Houston JM, Harris P, McIntire S, Francis D (2002) Revising the Competitiveness Index using Factor Analysis. Psychological Reports 90: 31-34.

Imas A (2014) Working for the warm glow: On the benefits and limits of prosocial incentives. Journal of Public Economics 114: 14-18.

Jacobsen KJ, Eika KH, Helland L, Lind JT, Nyborg K (2011) Are Nurses more Altruistic than Real Estate Brokers? Journal of Economic Psychology 32: 818-831. 
Kamas L, Preston A (2018) Competing with Confidence: The Ticket to Labor Market Success for College-Educated Women. Journal of Economic Behavior and Organization 155: 231-252.

Kolstad JR (2011) How can Rural Jobs be made more Attractive to Tanzanian Health Workers? Results from a Discrete Choice Experiment. Health Economics 20: 196-211.

Kolstad JR, Lindkvist I. (2013) Pro-Social Preferences and Self-Selection into the Public Health Sector: Evidence from an Economic Experiment. Health Policy and Planning 28: 320-327.

Kristof AL (1996) Person-Organization fit: an Integrative Review of its Conceptualizations, Measurement, and Implications. Personnel Psychology 49: 1-49.

Lagarde M, Blaauw D. (2016) Using Stated Choice Preferences to Investigate Job Preferences and Migration Patterns of South African Nurses. Unpublished manuscript.

Lancsar E, Denzil GF, Hole AR (2017) Discrete Choice Experiments: A Guide to Model Specification Estimation and Software. PharmacoEconomics 35: 697-716.

Layton D (2000) Random Coefficient Models for Stated Preference Surveys. Journal of Environmental Economics and Management 40: 21-36.

Mas A, Pallais A (2017) Valuing Alternative Work Arrangements. American Economic Review 107(12): 3722-59.

Mowen J (2004) Exploring the Trait of Competitiveness and Its Consumer Behavior Consequences. Journal of Consumer Psychology 14: 52-63.

Murphy KM, Shleifer A, Robert W, Vishny RW (1991) The Allocation of Talent: Implications for Growth. The Quarterly Journal of Economics 106: 503-530.

Perry JL, Hondeghem A, Wise LR (2010) Revisiting the Motivational Bases of Public Service: Twenty Years of Research and an Agenda for the Future. Public Administration Review 70: 681690.

Reuben E, Wiswall M, Zafar B (2017) Preferences and Biases in Educational Choices and Labor Market Expectations: Shrinking the Black Box of Gender. The Economic Journal 127: 21532186.

Reuben E, Sapienza P, Zingales L (2015) Competitiveness and the Gender Gap among Young Business Professionals. IZA Discussion Paper No 9446.

Revelt D, Train K (1998) Mixed Logit with Repeated Choices: Households' Choices of Appliance Efficiency Level. The Review of Economics and Statistics 80: 647-657. 
Smith C, Turner S (2017) The Millennial Majority is Transforming your Culture. Deloitte Academy report.

Tonin M, Vlassopoulos M (2010) Disentangling the Sources of Pro-socially Motivated Effort: A Field Experiment. Journal of Public Economics 94: 1086-1092.

Tonin M, Vlassopoulos M (2015) Corporate Philanthropy and Productivity: Evidence from an Online Real Effort Experiment. Management Science 61: 1795-1811.

Uggerslev KL, Fassina NE, Kraichy D (2012) Recruiting through the Stages: A Meta-Analytic Test of Predictors of Applicant Attraction at Different Stages of the Recruiting Process. Personnel Psychology 65: 597-660.

Wiswall M, Zafar B (2018) Preference for the Workplace Human Capital and Gender. Quarterly Journal of Economics, 133(1): 457-507.

Zhang L, Gowan MA (2012) Corporate Social Responsibility Applicants' Individual Traits and Organizational Attraction: A Person-Organization Fit Perspective. Journal of Business and Psychology 27: 345-362. 
Figures and Tables

Figure 1. Screenshot of discrete choice experiment

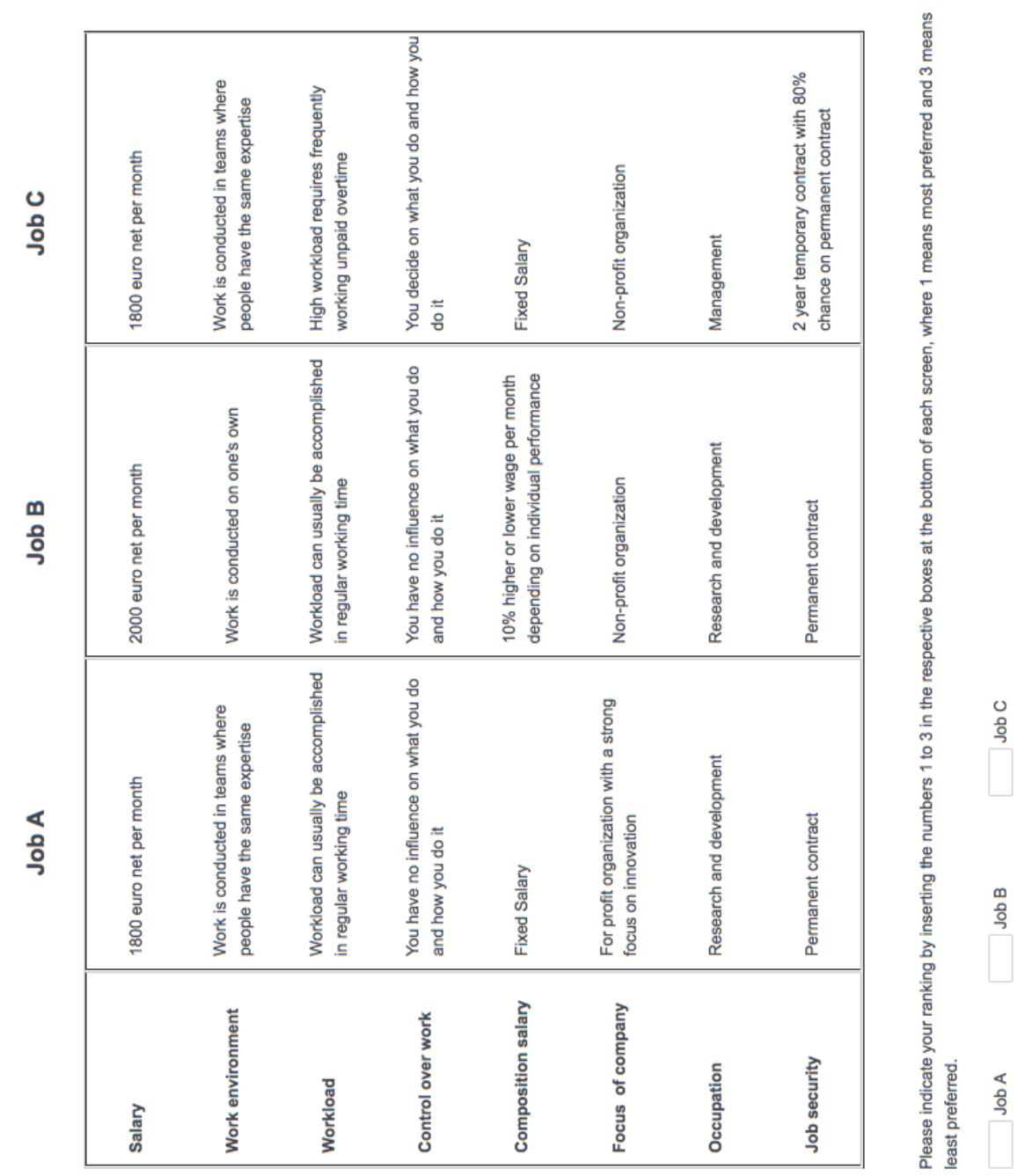


Figure 2. Estimated monetary value of job attributes

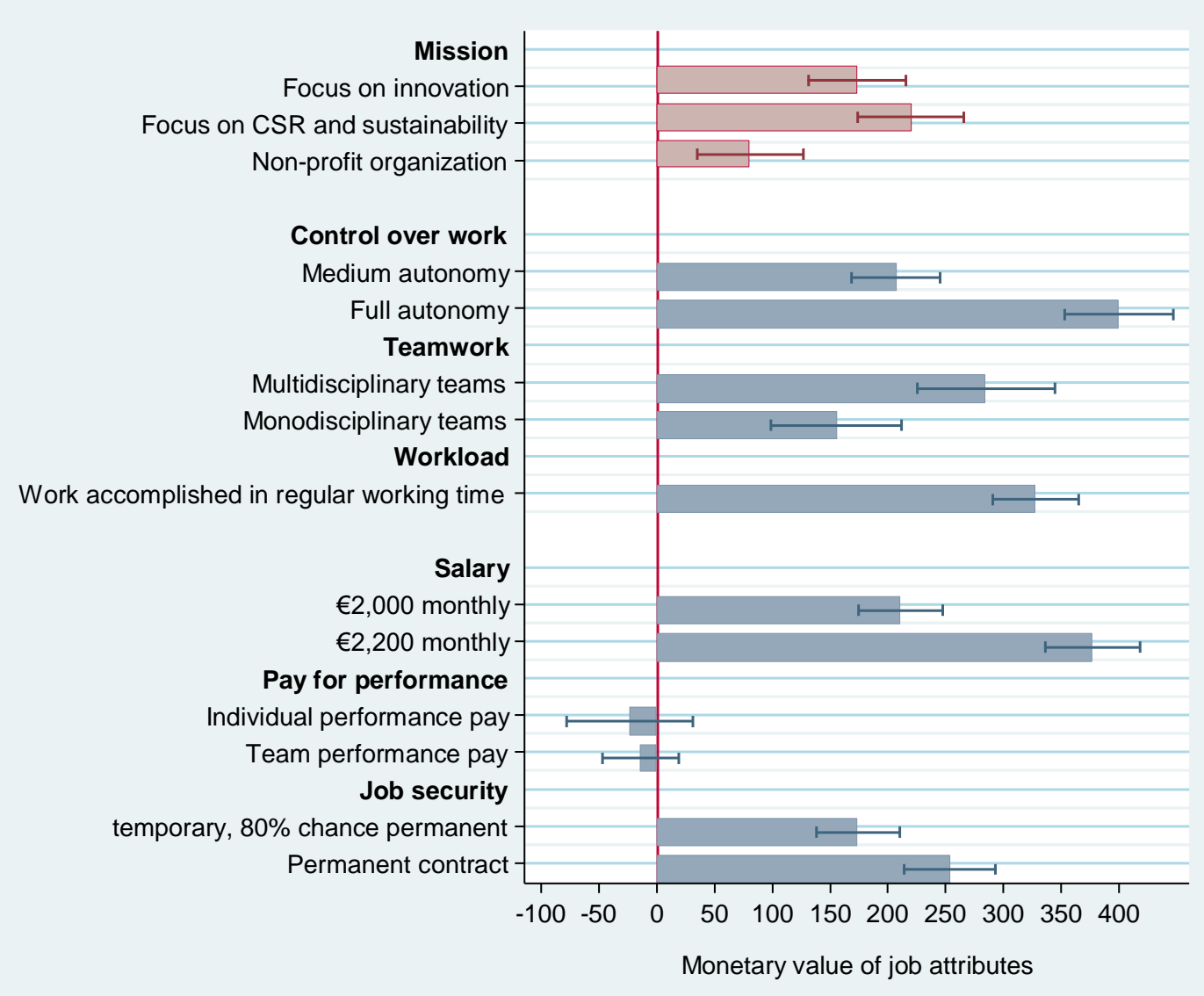


Table 1. Overview of job attributes and their values in the discrete choice experiment

Attributes

Values

\section{Mission}

Focus of the company

Workload

\begin{tabular}{ll}
\hline Salary & - $€ 1800$ netto per month \\
& - $€ 2000$ netto per month \\
Pay for performance & - Fixed salary \\
& - $10 \%$ higher or lower wage per month depending on individual \\
& - $10 \%$ herformance \\
- & 2 year temporary contract with $20 \%$ chance on permanent contract \\
Dob security & - 2 year temporary contract with $80 \%$ chance on permanent contract \\
- Permanent contract \\
- Research and development, \\
- Management, \\
\hline \hline
\end{tabular}

- For profit organization that is strongly profit orientated

- For profit organization with a strong focus on innovation

- For profit organization with a strong focus on corporate social responsibility and sustainability

- Non-profit organization
Job design

Autonomy: control

over own work

Teamwork
- You have no influence on what you do and how you do it.

- You have no influence on what you do, but you decide on how you do it.

- You decide on what you do and how you do it.

- Work is conducted on one's own,

- Work is conducted in multidisciplinary teams,

- Work is conducted in teams where people have the same expertise.

- High workload requires frequently working unpaid overtime.

- Workload can usually be accomplished in regular working time. 
Table 2. Descriptive statistics by university

\begin{tabular}{lcccc} 
& Eindhoven & Delft & Total & P-value \\
\hline Age & $25.42^{* * *}$ & 24.99 & 25.16 & 0.01 \\
Second-year MSc (\%) & $63 \%$ & $71 \% * * *$ & $68 \%$ & 0.002 \\
Gender (\% woman) & $27 \%$ & $36 \% * * *$ & $67 \%$ & 0.000 \\
Nationality: Dutch & $64 \%$ & $61 \%$ & $62 \%$ & 0.22 \\
Grade (1-10) & 7.47 & $7.57^{* *}$ & 7.53 & 0.019 \\
Self-Efficacy & 3.91 & 3.95 & 3.94 & 0.14 \\
Risk tolerance & 6.36 & 6.30 & 6.32 & 0.56 \\
Competitiveness & 3.16 & 3.11 & 3.13 & 0.34 \\
Trust & 3.28 & 3.28 & 3.28 & 1.00 \\
Altruism & -0.13 & $0.08^{* * *}$ & -0.01 & 0.00 \\
\hline $\mathrm{N}$ & 595 & 903 & 1498 &
\end{tabular}

Stars indicate significance of differences between Delft and Eindhoven: ** $\mathrm{p}<0.05, * * * \mathrm{P}<0.01$.

$\mathrm{P}$-values are based on two-sided tests with unequal variances. 
Table 3. Correlations between personal characteristics, personality traits and preferences

\begin{tabular}{|c|c|c|c|c|c|c|c|c|c|c|c|}
\hline & $\underset{\&}{\infty}$ & 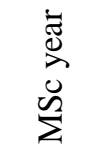 & $\stackrel{\dot{D}}{\stackrel{D}{\Delta}}$ & 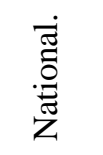 & $\begin{array}{l}\overline{\mathbb{v}} \\
\overline{0} \\
\mathbb{E}\end{array}$ & $\frac{\pi}{\pi}$ & 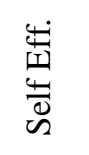 & $\frac{\dot{0}}{\frac{d}{a}}$ & 官 & $\overrightarrow{\underline{E}}$ & $\begin{array}{l}\text { E. } \\
\stackrel{\Xi}{\Xi} \\
\end{array}$ \\
\hline Age & 1.00 & & & & & & & & & & \\
\hline MSc year (2nd) & 0.17 & 1.00 & & & & & & & & & \\
\hline University (Delft) & -0.07 & 0.08 & 1.00 & & & & & & & & \\
\hline Nationality (Dutch) & -0.12 & 0.15 & -0.03 & 1.00 & & & & & & & \\
\hline Gender (woman) & -0.07 & -0.03 & 0.09 & -0.01 & 1.00 & & & & & & \\
\hline Grade & -0.06 & 0.07 & 0.06 & 0.00 & -0.01 & 1.00 & & & & & \\
\hline Self Efficacy & 0.00 & 0.05 & 0.04 & -0.03 & -0.05 & 0.18 & 1.00 & & & & \\
\hline Risk tolerance & 0.12 & -0.04 & -0.02 & -0.15 & -0.02 & 0.06 & 0.26 & 1.00 & & & \\
\hline Competitiveness & -0.08 & 0.03 & -0.02 & 0.07 & -0.13 & 0.10 & 0.28 & 0.22 & 1.00 & & \\
\hline Trust & -0.03 & 0.06 & 0.00 & 0.31 & 0.06 & -0.01 & 0.01 & 0.02 & -0.04 & 1.00 & \\
\hline Altruism & 0.07 & -0.07 & 0.09 & -0.28 & 0.06 & -0.03 & 0.00 & 0.18 & -0.13 & 0.04 & 1.00 \\
\hline
\end{tabular}

The interpretation of the highest value of binary variables is indicated between (). 
Table 4. Estimation results of mixed rank-ordered logit model

Method: Mixed rank-ordered logit

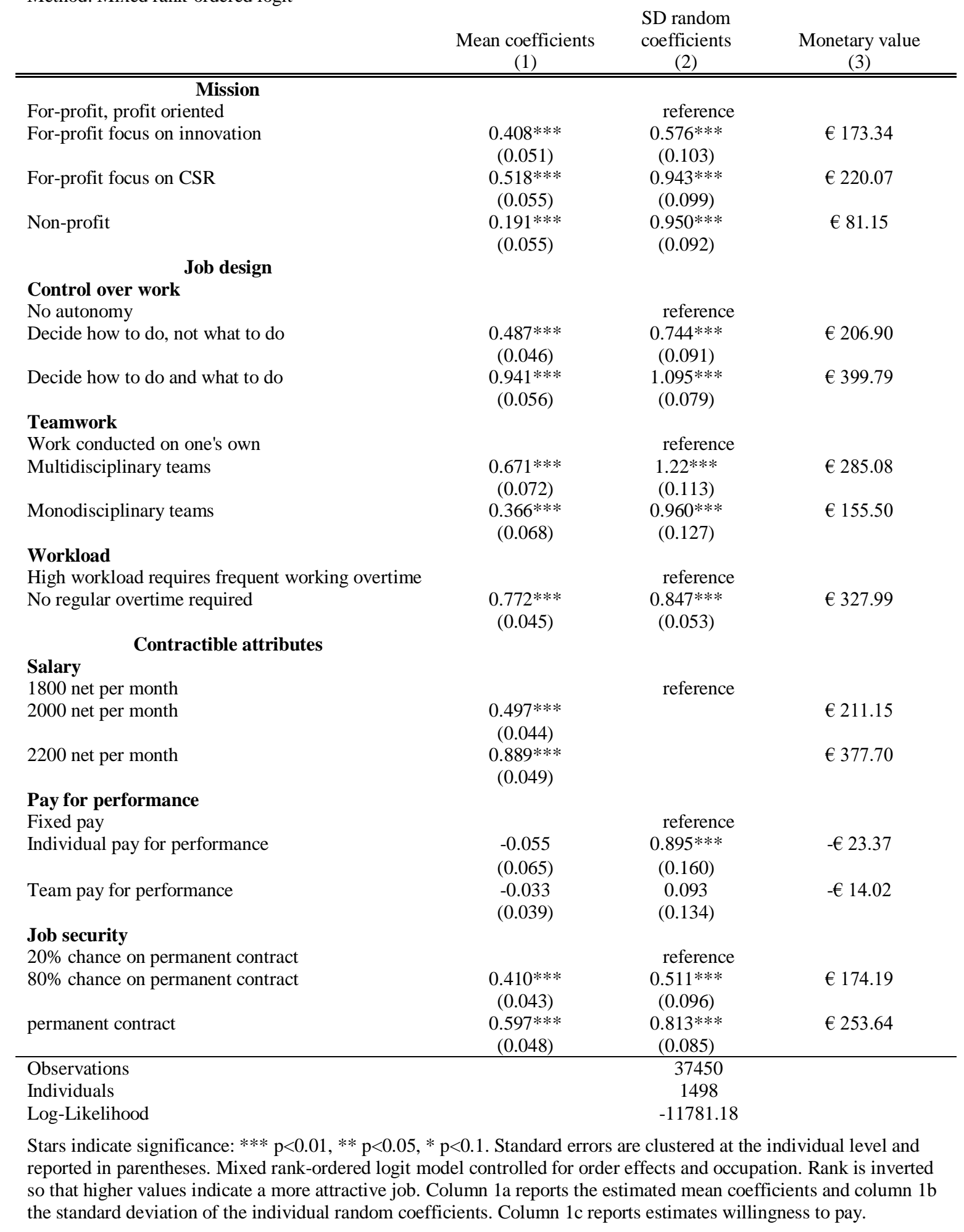


Table 5. Estimation results of mixed rank-ordered logit models interacted with individual characteristics

\begin{tabular}{|c|c|c|c|c|c|c|c|c|c|}
\hline Method: mixed rank-ordered logit & $\begin{array}{c}\text { Average } \\
\text { effects } \\
\text { (1a) } \\
\end{array}$ & $\begin{array}{l}\text { SD } \\
(1 \mathrm{~b}) \\
\end{array}$ & $\begin{array}{c}\text { \#Gender } \\
\text { (female) } \\
(1 \mathrm{c}) \\
\end{array}$ & $\begin{array}{c}\text { \#Grade } \\
(1 \mathrm{~d}) \\
\end{array}$ & $\begin{array}{c}\text { \#Self- } \\
\text { Efficacy } \\
(1 \mathrm{e}) \\
\end{array}$ & $\begin{array}{c}\text { \#Risk } \\
\text { Tolerance } \\
(1 \mathrm{f}) \\
\end{array}$ & $\begin{array}{c}\text { \#Competi- } \\
\text { tiveness } \\
(1 \mathrm{~g}) \\
\end{array}$ & $\begin{array}{l}\text { \#Trust } \\
\text { (1h) } \\
\end{array}$ & $\begin{array}{c}\text { \#Altruism } \\
\text { (1i) } \\
\end{array}$ \\
\hline \multicolumn{10}{|l|}{ Mission } \\
\hline For-profit, profit oriented & & & & & reference & & & & \\
\hline For-profit focus on innovation & $\begin{array}{c}0.555 * * * \\
(0.089)\end{array}$ & $\begin{array}{c}0.697 * * * \\
(0.107)\end{array}$ & $\begin{array}{c}0.296 * * * \\
(0.115)\end{array}$ & $\begin{array}{c}0.036 \\
(0.056)\end{array}$ & $\begin{array}{c}0.021 \\
(0.054)\end{array}$ & $\begin{array}{c}0.068 \\
(0.054)\end{array}$ & $\begin{array}{c}-0.125 * * \\
(0.056)\end{array}$ & $\begin{array}{l}-0.068 \\
(0.053)\end{array}$ & $\begin{array}{c}0.152 * * * \\
(0.053)\end{array}$ \\
\hline For-profit focus on CSR & $\begin{array}{c}0.569 * * * \\
(0.096)\end{array}$ & $\begin{array}{c}0.907 * * * \\
(0.127)\end{array}$ & $\begin{array}{c}0.447 * * * \\
(0.124)\end{array}$ & $\begin{array}{c}0.041 \\
(0.060)\end{array}$ & $\begin{array}{c}0.061 \\
(0.060)\end{array}$ & $\begin{array}{l}-0.016 \\
(0.060)\end{array}$ & $\begin{array}{c}-0.135 * * \\
(0.059)\end{array}$ & $\begin{array}{l}-0.022 \\
(0.055)\end{array}$ & $\begin{array}{c}0.195 * * * \\
(0.057)\end{array}$ \\
\hline Non-profit & $\begin{array}{c}0.295 * * * \\
(0.097)\end{array}$ & $\begin{array}{c}1.002 * * * \\
(0.129)\end{array}$ & $\begin{array}{c}0.364 * * * \\
(0.120)\end{array}$ & $\begin{array}{c}0.073 \\
(0.059)\end{array}$ & $\begin{array}{l}-0.016 \\
(0.059)\end{array}$ & $\begin{array}{l}-0.001 \\
(0.060)\end{array}$ & $\begin{array}{c}-0.259^{* * * *} \\
(0.062)\end{array}$ & $\begin{array}{c}-0.048 \\
(0.064)\end{array}$ & $\begin{array}{c}0.140 * * \\
(0.061)\end{array}$ \\
\hline \multicolumn{10}{|l|}{ Job design } \\
\hline \multicolumn{10}{|l|}{ Control over work } \\
\hline Decide how to do, not what to do & $\begin{array}{c}0.650 * * * \\
(0.076)\end{array}$ & $\begin{array}{c}0.640 * * * \\
(0.089)\end{array}$ & $\begin{array}{l}0.178^{*} \\
(0.105)\end{array}$ & $\begin{array}{c}0.112 * * * \\
(0.042)\end{array}$ & $\begin{array}{c}0.035 \\
(0.050)\end{array}$ & $\begin{array}{c}0.023 \\
(0.049)\end{array}$ & $\begin{array}{c}0.059 \\
(0.047)\end{array}$ & $\begin{array}{c}0.017 \\
(0.049)\end{array}$ & $\begin{array}{c}0.008 \\
(0.043)\end{array}$ \\
\hline Decide how to do and what to do & $\begin{array}{c}1.133 * * * \\
(0.090)\end{array}$ & $\begin{array}{c}0.986 * * * \\
(0.084)\end{array}$ & $\begin{array}{c}0.386 * * * \\
(0.118)\end{array}$ & $\begin{array}{c}0.071 \\
(0.049)\end{array}$ & $\begin{array}{c}0.078 \\
(0.056)\end{array}$ & $\begin{array}{c}0.030 \\
(0.059)\end{array}$ & $\begin{array}{c}0.107 * * \\
(0.051)\end{array}$ & $\begin{array}{c}0.082 \\
(0.058)\end{array}$ & $\begin{array}{c}0.012 \\
(0.053)\end{array}$ \\
\hline \multicolumn{10}{|l|}{ Teamwork } \\
\hline Work conducted on one's own & & & & & reference & & & & \\
\hline Multidisciplinary teams & $\begin{array}{c}1.161 * * * \\
(0.119)\end{array}$ & $\begin{array}{c}1.042 * * * \\
(0.115)\end{array}$ & $\begin{array}{l}-0.149 \\
(0.140)\end{array}$ & $\begin{array}{l}-0.013 \\
(0.073)\end{array}$ & $\begin{array}{c}0.061 \\
(0.073)\end{array}$ & $\begin{array}{c}0.099 \\
(0.075)\end{array}$ & $\begin{array}{c}0.047 \\
(0.070)\end{array}$ & $\begin{array}{c}0.152 * * \\
(0.071)\end{array}$ & $\begin{array}{c}-0.032 \\
(0.081)\end{array}$ \\
\hline Monodisciplinary teams & $\begin{array}{c}0.789 * * * \\
(0.116)\end{array}$ & $\begin{array}{c}0.828 * * * \\
(0.101)\end{array}$ & $\begin{array}{l}-0.251^{*} \\
(0.140)\end{array}$ & $\begin{array}{c}0.027 \\
(0.066)\end{array}$ & $\begin{array}{l}-0.060 \\
(0.067)\end{array}$ & $\begin{array}{c}0.048 \\
(0.070)\end{array}$ & $\begin{array}{l}-0.050 \\
(0.065)\end{array}$ & $\begin{array}{l}0.126^{*} \\
(0.071)\end{array}$ & $\begin{array}{l}-0.059 \\
(0.078)\end{array}$ \\
\hline \multicolumn{10}{|l|}{ Workload } \\
\hline No regular overtime required & $\begin{array}{c}0.958 * * * \\
(0.072)\end{array}$ & $\begin{array}{c}0.778 * * * \\
(0.063)\end{array}$ & $\begin{array}{c}0.132 \\
(0.083)\end{array}$ & $\begin{array}{l}-0.003 \\
(0.037)\end{array}$ & $\begin{array}{r}-0.065 \\
(0.044)\end{array}$ & $\begin{array}{c}-0.136 * * * \\
(0.043)\end{array}$ & $\begin{array}{l}-0.041 \\
(0.043)\end{array}$ & $\begin{array}{c}0.019 \\
(0.040)\end{array}$ & $\begin{array}{c}0.001 \\
(0.040)\end{array}$ \\
\hline \multicolumn{10}{|l|}{ Contractible attributes } \\
\hline $\begin{array}{l}\text { Salary } \\
1800 \text { net per month }\end{array}$ & & & & & reference & & & & \\
\hline 2000 net per month & $\begin{array}{l}0.713 * * * \\
(0.077)\end{array}$ & & $\begin{array}{l}-0.011 \\
(0.095)\end{array}$ & $\begin{array}{l}-0.047 \\
(0.044)\end{array}$ & $\begin{array}{c}0.017 \\
(0.043)\end{array}$ & $\begin{array}{c}0.011 \\
(0.048)\end{array}$ & $\begin{array}{l}0.078^{*} \\
(0.045)\end{array}$ & $\begin{array}{l}-0.034 \\
(0.047)\end{array}$ & $\begin{array}{l}-0.068 \\
(0.045)\end{array}$ \\
\hline 2200 net per month & $\begin{array}{l}1.253 * * * \\
(0.085)\end{array}$ & & $\begin{array}{l}-0.001 \\
(0.101)\end{array}$ & $\begin{array}{l}-0.082^{*} \\
(0.049)\end{array}$ & $\begin{array}{c}0.071 \\
(0.050)\end{array}$ & $\begin{array}{l}0.108 * * \\
(0.050)\end{array}$ & $\begin{array}{l}0.140 * * * \\
(0.051)\end{array}$ & $\begin{array}{l}-0.031 \\
(0.052)\end{array}$ & $\begin{array}{c}-0.163 * * * \\
(0.051)\end{array}$ \\
\hline
\end{tabular}


Table 5. Continued

\section{Pay for performance}

Fixed pay

Individual pay for performance

0.089

(0.114)

Team pay for performance

$-0.040$

$0.616^{* * *}$

$-0.361 * *$
reference
0.026

(0.207)

(0.070)

0.242

$(0.141)$
-0.116

$(0.069)$
-0.047

0.029
$(0.071)$
0.046

\section{Job security}

$20 \%$ chance on permanent contract

$80 \%$ chance on permanent contract

$0.555 * * *$

(0.153)

(0.088)

$(0.037)$

(0.044)

0.086
$(0.072)$

0.059

(0.072)

0.042

0.011

(0.069)

$-0.040$

$(0.075)$

$0.383 * * *$

0.053 reference

$0.693 * * *$

$(0.136)$
$0.766 * * *$

0.053

(0.097)

permanent contract

$(0.080)$

$(0.087)$

0.085

$-0.045$

$(0.056)$

$\begin{array}{ll}0.010 & 0.017\end{array}$

0.017

$-0.078$

$(0.043)$

$0.041)$

0.021

Observations

35725

35725

$\begin{array}{cc}0.043 & 0.036 \\ (0.045) & (0.046)\end{array}$

1429

Stars indicate significance: $* * * \mathrm{p}<0.01, * * \mathrm{p}<0.05,{ }^{*} \mathrm{p}<0.1$. Standard errors are clustered at the individual level and reported in parentheses. Mixed rank-ordered logit

regression of job rank on job attributes, interacted with university, nationality, and all individual characteristics. Occupation and order effects are included, but not reported.

Individual characteristics are standardized. Rank is inverted so that higher values indicate a more attractive job. Columns (1a) and (1b) report main effects and standard deviation of individual coefficients, respectively. 


\section{Appendix: Follow-up questionnaire}

To test whether the preferences of the respondents in our stated-choice experiment are reflected in their job satisfaction when they are employed, we have sent a short follow-up questionnaire to the graduates of the Eindhoven University of Technology who gave us permission to do so. We conducted this survey in October 2018, i.e., more than three years after the initial survey. Of the 374 individuals contacted, 118 completed the survey (32\% response rate). Of these graduates, 7 were not employed and 3 did not complete all survey questions, leaving us with 108 complete responses. Apart from gender and nationality, we do not observe statistically significant differences in personal characteristics between individuals who participated in the initial sample, but did not participate in the follow-up survey. The respondents to the follow-up survey seem more representative for the whole student population of Eindhoven University of Technology than our initial survey sample. In our follow-up survey, 19\% of respondents is female, compared to $20 \%$ in the student population and $27 \%$ of initial survey participants. Our follow-up survey consists of $71 \%$ Dutch nationals, which is more than in the initial survey (64\%) but still an underrepresentation compared to the student population (82\% Dutch).

We asked respondents to describe their current job with regard to the same job attributes we included in the hypothetical choice experiment. Table A1 provides an overview of the questions we asked to describe the current job, as well as the response frequencies. Most questions force respondents to make a choice between two or three answer categories. An exception is mission of the company. Respondents rate the importance of profit, innovation, and CSR on a 11point Likert scale, respectively. To give an impression of the distribution, we reclassify their answers into three different categories: Not important (0-5), Important (6-8), Very Important (910). A focus on innovation is rated highest. With regard to the other questions, we observe quite some variation in the answers. This confirms that the range of values in the discrete choice experiment is generally relevant for graduates' job choice.

We regress these characteristics on job satisfaction as measured on a 11-point Likertscale (average score 7.58, standard deviation 1.55). We transform the ratings of the importance of profit, innovation and CSR mission of the company as follows. We calculate the importance ratings of innovation and CSR relative to the importance rating of profit, then take the log of this ratio and standardize. The estimation results are reported in Table A2. In the first column, we control for gender and nationality. In the second column, we add potentially endogenous controls such as tenure, whether the workplace is located in the Netherlands, and occupation. Interestingly, 
we find that respondents who report working in an organization with a strong emphasis on innovation relative to profit are more satisfied with their job. This finding is in line with the findings from our discrete choice experiment. However, we do not find that those who work in organizations emphasizing CSR are more satisfied with their job.

Consistent with our hypothetical choice experiment, graduates who report having more autonomy also report significantly higher job satisfaction. As expected, teamwork is also associated with higher job satisfaction, although this effect is only statistically significant when teams are monodisciplinary. Workload is negatively associated with job satisfaction, but this effect is not statistically significant. Finally, a permanent contract is reflected in higher job satisfaction, while performance pay has no statistically significant effect.

It would be interesting to analyze whether there is a relation between individuals' preferences expressed in the experiment and attributes of their current job. Unfortunately, the sample size $(\mathrm{N}=108)$ is too limited for such an analysis. Moreover, since job characteristics are self-reported, individuals with stronger preferences are likely to be more critical in their evaluation, biasing results towards zero. Given the small number of observations and lack of exogenous variation, we should be careful not to overinterpret the findings above. Nevertheless, they provide some evidence that workers care about the job attributes that show up as important in the hypothetical discrete choice experiment. 
Table A1. Follow-up survey: descriptive statistics on respondents' current job

How would you describe your organization: profit or non-profit?

Non-Profit

Profit

How important is profit in the culture of your company?

Not important

Important

Very important

How important is innovation in the culture of your company?

Not important

Important

Very important

How important is CSR in the culture of your company?

Not important

Important

Very important

How much autonomy do you have in your job?

No influence at all

No influence on what you do, only on how to do it

Influence on what you do and how you do it

How is work typically conducted?

Conducted on your own

Teams where people have the same expertise

Work is conducted in multidisciplinary teams

How would you describe your workload?

Moderate workload

High workload, requires frequent overtime

Does your salary include performance-related components?

No

Yes

What describes your employment prospects best?

No prospect on permanent contract

Good prospect on permanent contract

Permanent contract
N

$77 \quad 71 \%$

$31 \quad 29 \%$

Percent

$32 \%$

$68 \%$

$43 \quad 40 \%$

$37 \quad 34 \%$

$28 \quad 26 \%$

$15 \quad 14 \%$

$46 \quad 43 \%$

$47 \quad 44 \%$

$28 \quad 26 \%$

$58 \quad 54 \%$

$22 \quad 20 \%$

$2 \quad 2 \%$

$40 \quad 37 \%$

$66 \quad 61 \%$

$35 \quad 32 \%$

$23 \quad 21 \%$

$50 \quad 46 \%$

$74 \quad 69 \%$

$34 \quad 31 \%$

$65 \quad 60 \%$ 
Table A2. Follow-up survey: current job characteristics and job satisfaction

Method: OLS
Job satisfaction

(1)

$\begin{array}{cc}1.002 * * * & 0.861 * * \\ (0.323) & (0.343) \\ -0.125 & -0.123 \\ (0.287) & (0.296)\end{array}$

\section{Autonomy}

No or little autonomy

Full autonomy

\section{Teamwork}

Mostly individual

Teamwork: monodisciplinary

Teamwork: multidisciplinary

\section{Workload}

Moderate workload

High workload, frequent overtime

\section{Performance-related pay}

no

yes

\section{Job security}

No prospect on permanent contract

good prospect on permanent contract

Permanent contract

\section{Gender}

Male

Female

\section{Nationality}

Non-Dutch

Dutch

Controls: tenure, workplace in Netherlands, occupation Observations

R-squared

$\begin{array}{ccc} & \text { reference } & \\ 0.599 * * & & 0.577 * \\ (0.301) & & (0.307)\end{array}$

$\begin{array}{cc} & \text { reference } \\ 0.973 * * * & 0.964 * * * \\ (0.364) & (0.352) \\ 0.492 & 0.496 \\ (0.299) & (0.305)\end{array}$

reference

$-0.470$

$-0.453$

(0.316)

$(0.335)$

reference

$0.361 \quad 0.231$

$(0.253) \quad(0.263)$

reference

$1.010 * * \quad 1.061 * *$

(0.480) (0.433)

$1.494 * * * \quad 1.609 * * *$

(0.478)

(0.459)

reference

$\begin{array}{ll}-0.090 & -0.169\end{array}$

$(0.420) \quad(0.468)$

reference

0.275

(0.297)

No

(0.368)

$0.37 \quad 0.41$

Stars indicate significance: $* * * p<0.01, * * \mathrm{p}<0.05, * \mathrm{p}<0.1$. Robust standard errors in parentheses. The importance of innovation relative to profit is defined as the log of the ratio of the importance of innovation over the importance of profit, both rated on a 11-point Likert scale. The importance of CSR relative to profit is defined similarly. These two variables are standardized for ease of interpretation. 